\title{
Impact of Cannabinoid Receptor Ligands on Sensitisation to Methamphetamine Effects on Rat Locomotor Behaviour
}

\author{
L. LANDA, K. ŠLAIS, A. ŠULCOVÁ \\ Department of Pharmacology, Faculty of Medicine, Masaryk University Brno, \\ Czech Republic \\ Received August 24, 2007 \\ Accepted February 14, 2008
}

\begin{abstract}
Landa L., K Šlais, A. Šulcová: Impact of Cannabinoid Receptor Ligands on Sensitisation to Methamphetamine Effects on Rat Locomotor Behaviour. Acta Vet Brno 2008, 77: 183-191.

The repeated administration of various drugs of abuse may lead to a gradually increased behavioural response to these substances, particularly an increase in locomotion and stereotypies may occur. This phenomenon is well known and described as behavioural sensitisation. An increased response to the drug tested, elicited by previous repeated administration of another drug is recognised as cross-sensitisation. Based on our earlier experiences with studies on mice, which confirmed sensitisation to methamphetamine and described cross-sensitisation to methamphetamine after pre-treatment with cannabinoid $\mathrm{CB}_{1}$ receptor agonist, we focused the present study on the use of another typical laboratory animal - the rat. A biological validity of the sensitisation phenomenon was expected to be enhanced if the results of both mouse and rat studies were conformable. Similar investigation in rats brought very similar results to those described earlier in mice. However, at least some interspecies differences were noted in the rat susceptibility to the development of sensitisation to methamphetamine effects. Comparing to mice, it was more demanding to titrate a dose of methamphetamine producing behavioural sensitisation. Furthermore, we were not able to provoke cross-sensitisation by repeated administration of cannabinoid $\mathrm{CB}_{1}$ receptor agonist methanandamide and similarly, we did not demonstrate the suppression of cross-sensitisation in rats that were repeatedly given combined pre-treatment with cannabinoid $\mathrm{CB}_{1}$ receptor antagonist $\mathrm{AM} 251$ and methamphetamine. Finally, unlike mice, an alternative behavioural change was registered after repeated methamphetamine treatment instead: the occurrence of stereotypic behaviour (nose rubbing).
\end{abstract}

Behavioural sensitisation, cannabinoids, open field test, rats

Repeated administration of various drugs of abuse may lead to an increase in behavioural response to these substances, which has been described as behavioural sensitisation (Robinson and Berridge 1993). Behavioural sensitisation may be observed both in laboratory animals and humans (Tzschentke and Schmidt 1997) and its manifestation may vary in different species (Lanis and Schmidt 2001). It refers to the progressive augmentation of behavioural responses to re-application of the drug and the so-called "challenge dose" of the same drug even after a certain period of its withdrawal. This has been described for several drugs of abuse including psychostimulants (Costa et al. 2001; Elliot 2002), opioids (De Vries et al. 1999) or cannabinoids (Cadoni et al. 2001). It has been also found, that an increased response to a drug may be elicited by previous repeated administrations of a drug different from the challenge dose of the drug tested. This is termed cross-sensitisation and has been manifested for example with tetrahydrocannabinol to opioids (Cadoni et al. 2001; Lamarque et al. 2001). Both behavioural sensitisation and cross-sensitisation are considered to be responsible for reinstating the drug-seeking behaviour (DeVries et al. 2002).

There is increasing evidence indicating that behavioural sensitisation can be parcelled into two temporally defined domains, called development (or initiation) and expression (Kalivas et al. 1993). The term "development" of behavioural sensitisation refers to the

Address for correspondence:

MVDr. Leoš Landa, PhD.

Masaryk University, Faculty of Medicine

Department of Pharmacology

Phone: +420 549495097

Fax: +420 549492364

Tomešova 12, 60200 Brno, Czech Republic

E-mail: landa@med.muni.cz

http://www.vfu.cz/acta-vet/actavet.htm 
progressive molecular and cellular alterations that culminate in a change in the processing of environmental and pharmacological stimuli by the CNS. These alterations are transient and may not be detected after a few weeks of withdrawal (Kalivas et al. 1993). The term "expression" of behavioural sensitisation is defined as enduring neural changes that arise from the process of development that directly mediates the sensitised behavioural response (Pierce and Kalivas 1997). Various data indicate that these processes are distinct not only temporally but also anatomically. Development of behavioural sensitisation to psychostimulant drugs occurs in the ventral tegmental area and substantia nigra, which are the loci of the dopamine cells in the ventral midbrain that give rise to the mesocorticolimbic and nigrostriatal pathways. In contrast, the neuronal events associated with expression are distributed among several interconnected limbic nuclei that are centred on the nucleus accumbens (Pierce and Kalivas 1997).

In our previous studies on mice we observed development of behavioural sensitisation to methamphetamine and also cross-sensitisation with cannabinoid $\mathrm{CB}$ receptor agonist methanandamide to methamphetamine in the mouse open field test (Landa et al. 2006a) as well as in the mouse model of agonistic behaviour (Landa et al. 2006b). Furthermore, in the same animal models we were able to block this cross-sensitisation using pre-treatment with cannabinoid $\mathrm{CB}_{1}$ receptor antagonist - substance AM 251 prior to the methamphetamine challenge dose. These data were to a large extent in accordance with earlier findings from our laboratory that supported the hypothesis about interaction between endocannabinoid system and methamphetamine brain mechanisms (Vinklerová et al. 2002). Thus, we decided to extend our research trying to elicit sensitisation to methamphetamine and crosssensitisation to methanandamide in another laboratory rodent - rat, similarly in the open field test. If the results correlated well, the general biomedical validity of the study would be of greater impact.

\section{Materials and Methods}

Animals

Rat males (strain Wistar, BioTest, s.r.o., Konárovice, Czech Republic) with a starting weight of 290 - $310 \mathrm{~g}$ were used. Rats were housed with free access to water and food in a room with controlled humidity and temperature maintained under a 12-h phase lighting cycle. Experimental sessions were always performed in the same light period (between 13:00 - 15:00 h) in order to minimise possible variability due to circadian rhythms.

The experimental protocols of all experiments comply with the European Community guidelines for the use of experimental animals and were approved by the Animal Care Committee of the Masaryk University Brno, Faculty of Medicine, Czech Republic.

Open field test

Behavioural activities were measured using an open-field equipped with Actitrack (Panlab, S. L., Spain). This device consists of two square-shaped frames that deliver beams of infrared rays into the space inside the square. A plastic box is placed in this square to act as an open-field arena (base $45 \times 45 \mathrm{~cm}$, height $25 \mathrm{~cm}$ ), in which the animal can move freely. The apparatus software records and evaluates the behavioural activities of the animal by registering the beam interruptions caused by movements of the body. With this device, it is possible to monitor various behavioural indicators. For our purposes, we have chosen Distance Travelled.

Drugs

Vehicle and all drugs were always given in a volume adequate to drug solutions $(2 \mathrm{ml} / \mathrm{kg})$ :

(+)methamphetamine, (d-N, $\alpha$-dimethylphenylethylamine;d-desoxyephedrine), (Sigma Chemical Co.) dissolved in saline;

(R)-(+)-methanandamide, (R)-N-(2-hydroxy-1-methylethyl)-5Z,8Z,11Z-eicosotetraenamide), (Tocris Cookson Ltd., UK) in solution (anhydrous ethanol, $5 \mathrm{mg} / \mathrm{ml}$ ) dissolved in saline;

AM251,(N-(piperidine-1-yl)-5-(4-iodophenyl)-1-(2,4-dichlorophenyl)-4-methyl-1H-pyrazole-3-carboxamide), (Tocris Cookson Ltd., UK), ultrasonically suspended in Tween 80.

Procedure

In the dose-response Experiments I - III, the effects of different doses of methamphetamine on ambulatory activity in rats were tested. The drug treatments for Days $7-13$ were provided in the following regimen: Experiment I: 1) vehicle at the dose of $2.0 \mathrm{ml} / \mathrm{kg} /$ day $\left.\left(\mathrm{n}_{1}=6\right), 2\right)$ methamphetamine at the dose of $5.0 \mathrm{mg} / \mathrm{kg} / \mathrm{day}$ $\left(\mathrm{n}_{2}=6\right)$; Experiment II: 1) vehicle at the dose of $2.0 \mathrm{ml} / \mathrm{kg} /$ day $\left.\left(\mathrm{n}_{1}=6\right), 2\right)$ methamphetamine at the dose of 2.5 
$\mathrm{mg} / \mathrm{kg} /$ day $\left(\mathrm{n}_{2}=6\right)$; Experiment III: 1$)$ vehicle at the dose of $\left.2.0 \mathrm{ml} / \mathrm{kg} / \mathrm{day}\left(\mathrm{n}_{1}=8\right), 2\right)$ methamphetamine at the dose of $2.5 \mathrm{mg} / \mathrm{kg} /$ day $\left(\mathrm{n}_{2}=8\right)$. On Day 14, all rats in all groups received a "challenge dose" of methamphetamine (in the Experiment I at the dose of $5.0 \mathrm{mg} / \mathrm{kg}$, in the experiment II at a dose of $2.5 \mathrm{mg} / \mathrm{kg}$ and in the Experiment III at the dose of $1.0 \mathrm{mg} / \mathrm{kg}$ ). Locomotor activity in the open field was recorded in naive animals on Day 1 and 15 minutes after each application on Days 7 and 14 of the Experiments using the Actitrack apparatus.

In the Experiment IV rats were randomly divided into three groups, all were administered vehicle intraperitoneally $(2.0 \mathrm{ml} / \mathrm{kg})$ and their ambulatory activity in the open field was recorded 15 min after application using the Actitrack apparatus (the $1^{\text {st }}$ record) on Day 1 . No observations or drug applications were carried out from Day 2 to Day 6. On Day 7, rats were given a dose of the drug treatment or vehicle (i.p.), followed, after 15 min, by the open field test (the $2^{\text {nd }}$ record). Between Day 8 and Day 14, the animals in all groups were given once a day the same drugs at the same doses. On Day 14, ambulatory activity was recorded in the Actitrack apparatus $\left(3^{\text {rd }}\right.$ record), $15 \mathrm{~min}$ after application. There was a pause without applications from Day 15 to Day 20. On Day 21 all animals in all groups received a "challenge dose" of methamphetamine $(0.5 \mathrm{mg} / \mathrm{kg})$ and $15 \mathrm{~min}$ after application their ambulation was measured in the Actitrack Apparatus ( $4^{\text {th }}$ record). The drug treatments for Days $7-14$ were provided in the following design: 1) methamphetamine at the dose of $\left.0.5 \mathrm{mg} / \mathrm{kg} / \mathrm{day}\left(\mathrm{n}_{1}=6\right), 2\right)$ methanandamide at the dose of $1.0 \mathrm{mg} / \mathrm{kg} /$ day $\left.\left(\mathrm{n}_{2}=7\right), 3\right)$ combined treatment with methamphetamine + AM 251 at the dose of 0.5 $\mathrm{mg} / \mathrm{kg} /$ day and $2.0 \mathrm{mg} / \mathrm{kg} /$ day, respectively $\left(\mathrm{n}_{3}=6\right)$.

Statistical analysis

Animals in these experiments served as their own controls and because the data were not normally distributed (according to preliminary evaluation in the Kolmogorov-Smirnov test of normality), non-parametric statistics was used: Wilcoxon test, two tailed.

\section{Results}

The results obtained from Experiment I showed a significant $(p<0.05)$ increase in Distance Travelled after the acute administration of methamphetamine $(5.0 \mathrm{mg} / \mathrm{kg})$ compared to naive animals (the $1^{\text {st }}$ record versus the $2^{\text {nd }}$ record), whereas the "challenge dose" of methamphetamine led to a significant $(p<0.05)$ decrease in Distance Travelled (the $2^{\text {nd }}$ record versus the $3^{\text {rd }}$ record) - see Fig. 1 . In this experiment we noticed quite frequent occurrence of stereotypic acts, namely nose rubbing, after the "challenge dose" of methamphetamine, however, an objective quantification was not available.

In Experiment II, the acute administration of methamphetamine $(2.5 \mathrm{mg} / \mathrm{kg})$ resulted in a significant $(p<0.05)$ increase in Distance Travelled (the $1^{\text {st }}$ record versus the $2^{\text {nd }}$ record), decrease in the same behavioural indicator was non-significant $(p>0.05)$ after the "challenge dose" (the $2^{\text {nd }}$ record versus the $3^{\text {rd }}$ record) (Fig. 1). Also in this experiment we observed an increased frequency of stereotypic nose rubbing after the "challenge dose" of methamphetamine. Unfortunately, similarly to the previous experiment, we were not able to quantify exactly this indicator of behaviour using our technical equipment.

In Experiment III, the acute administration of methamphetamine $(2.5 \mathrm{mg} / \mathrm{kg})$ elicited a significant $(p<0.05)$ increase in Distance Travelled (the $1^{\text {st }}$ record versus the $2^{\text {nd }}$ record) and the "challenge dose" of methamphetamine $(1.0 \mathrm{mg} / \mathrm{kg})$ following repeated methamphetamine pre-treatment with higher doses led to further increase in Distance Travelled (the $2^{\text {nd }}$ record versus the $3^{\text {rd }}$ record), nevertheless, this change was not significant $(p>0.05)$ (Fig. 1).

In Experiment IV, the acute administration of methamphetamine led to a significant increase $(p<0.05)$ in Distance Travelled (group $\mathrm{n}_{1}$, the $2^{\text {nd }}$ record) compared to the animals that were given vehicle (group $\mathrm{n}_{1}$, the $1^{\text {st }}$ record). Repeated administration of methamphetamine resulted in the same group in significant $(p<0.05)$ development of sensitisation (group $\mathrm{n}_{1}$, the $3^{\text {rd }}$ record versus the $2^{\text {nd }}$ record) and this variable remained increased also after methamphetamine "challenge dose" on Day 21, following a pause lasting for six days without any applications (group $n_{1}$, the $4^{\text {th }}$ record versus the $3^{\text {rd }}$ record). Distance Travelled in the $4^{\text {th }}$ record was also significantly increased $(p<0.05)$ comparing to data obtained in this variable during the $1^{\text {st }}$ record (Fig. 2).

The acute administration of methanandamide resulted in a significant $(p<0.01)$ decrease in Distance Travelled (group $\mathrm{n}_{2}$, the $2^{\text {nd }}$ record) compared to the animals that were 
Fig. 1. Effects of drug treatments in Experiments I, II and III on Distance Travelled (cm/3 min) in the rat open field test shown as median values.

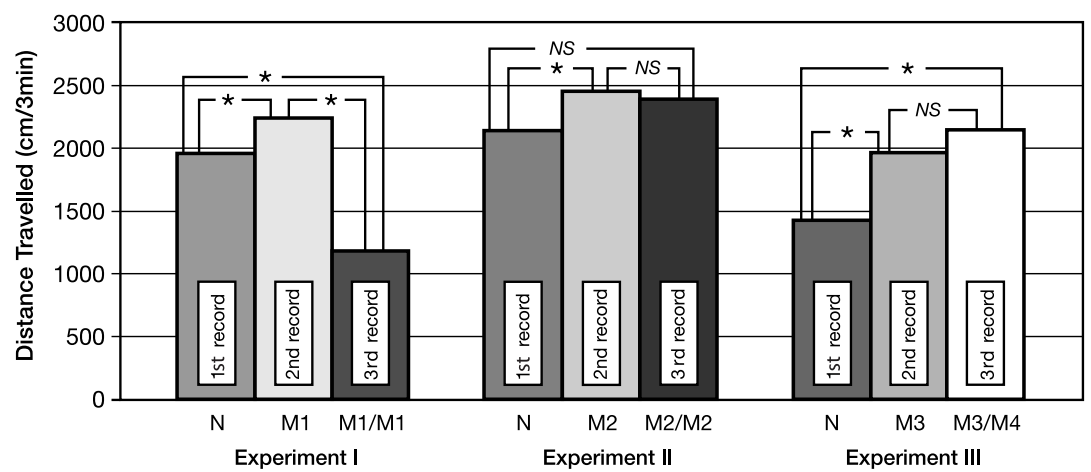

$\mathrm{N}=$ naive rats, $\mathrm{M} 1=$ rats after the $1^{\text {st }}$ dose of methamphetamine $(5.0 \mathrm{mg} / \mathrm{kg}), \mathrm{M} 1 / \mathrm{M} 1$ rats pre-treated with methamphetamine $(5.0 \mathrm{mg} / \mathrm{kg})$ after the methamphetamine "challenge dose" $(5.0 \mathrm{mg} / \mathrm{kg}), \mathrm{M} 2=$ rats after the $1^{\text {st }}$ dose of methamphetamine $(2.5 \mathrm{mg} / \mathrm{kg}), \mathrm{M} 2 / \mathrm{M} 2$ rats pre-treated with methamphetamine $(2.5 \mathrm{mg} / \mathrm{kg}) \mathrm{after}$ the methamphetamine "challenge dose" $(2.5 \mathrm{mg} / \mathrm{kg}), \mathrm{M} 3=$ rats after the $1^{\text {st }}$ dose of methamphetamine $(2.5 \mathrm{mg} / \mathrm{kg})$, M3/M4 rats pre-treated with methamphetamine $(2.5 \mathrm{mg} / \mathrm{kg})$ after the methamphetamine "challenge dose" (1.0 $\mathrm{mg} / \mathrm{kg})$

$*=p<0.05, * *=p<0.01, \mathrm{NS}=$ non-significant - non-parametric Wilcoxon matched pairs test.

Fig. 2. Effects of drug treatments in Experiment IV (subgroup $\left.\mathrm{n}_{1}\right)$ on Distance Travelled $(\mathrm{cm} / 3 \mathrm{~min})$ in the rat open field test shown as median values.

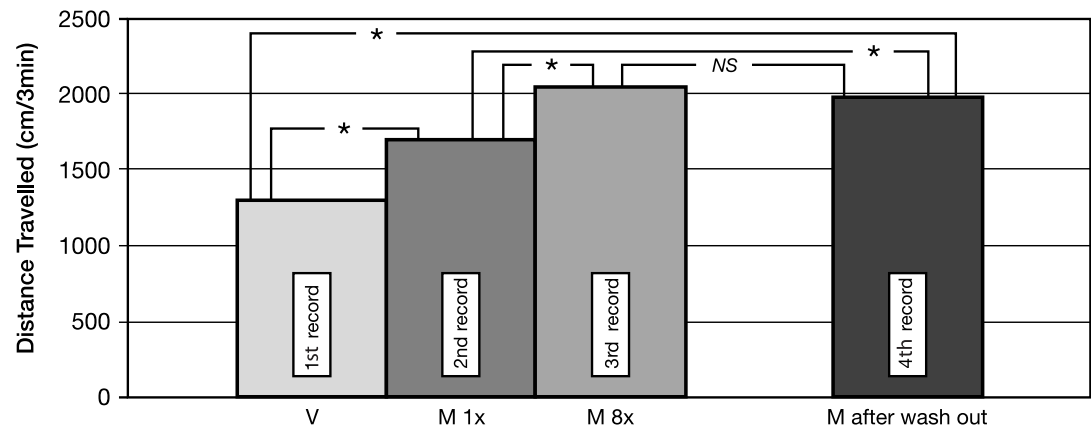

$\mathrm{V}=$ rats after the $1^{\text {st }}$ dose of vehicle $(2.0 \mathrm{ml} / \mathrm{kg}), \mathrm{M} 1 \mathrm{x}=$ rats after the $1^{\text {st }}$ dose of methamphetamine $(0.5 \mathrm{mg} / \mathrm{kg})$, $\mathrm{M} 8 \mathrm{x}=$ rats pre-treated with methamphetamine after the $8^{\text {th }}$ methamphetamine dose $(0.5 \mathrm{mg} / \mathrm{kg})$, M after washout $=$ rats pre-treated with methamphetamine after methamphetamine ,challenge dose” $(0.5 \mathrm{mg} / \mathrm{kg})$ following six days lasting wash-out period

$*=p<0.05, * *=p<0.01, \mathrm{NS}=$ non-significant - the non-parametric Wilcoxon matched pairs test.

administered vehicle (group $\mathrm{n}_{2}$, the $1^{\text {st }}$ record). Repeated administration of methanandamide elicited in the same group a more pronounced decrease in Distance Travelled (group $\mathrm{n}_{2}$, the $3^{\text {rd }}$ record versus the $2^{\text {nd }}$ record); however, it did not reach statistical significance $(p>0.05)$. After the six day wash-out and application of methamphetamine "challenge dose" on Day 21 Distance Travelled in rats pre-treated with methanandamide was significantly increased (group $\mathrm{n}_{2}$, the $4^{\text {th }}$ record versus the $3^{\text {rd }}$ record), nevertheless, there was no significant difference in this indicator between the $1^{\text {st }}$ and the $4^{\text {th }}$ record $(p>0.05)$ (Fig. 3).

The acute use of a combined treatment with methamphetamine + AM 251 provoked non-significant $(p>0.05)$ changes in Distance Travelled (group $\mathrm{n}_{3}$, the $2^{\text {nd }}$ record) 
Fig. 3. Effects of drug treatments in Experiment IV (subgroup $\mathrm{n}_{2}$ ) on Distance Travelled $(\mathrm{cm} / 3 \mathrm{~min})$ in the rat open field test shown as median values.

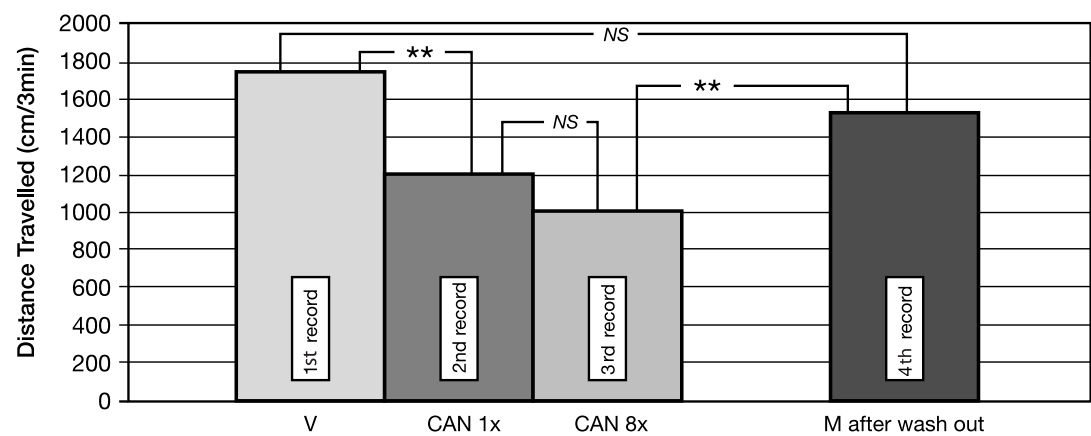

$\mathrm{V}=$ rats after the $1^{\text {st }}$ dose of vehicle $(2.0 \mathrm{ml} / \mathrm{kg}), \mathrm{CAN} 1 \mathrm{x}=$ rats after the $1^{\text {st }}$ dose of methanandamide $(1.0 \mathrm{mg} / \mathrm{kg})$, CAN $8 \mathrm{x}=$ rats pre-treated with methanandamide after the $8^{\text {th }}$ methanandamide dose $(1.0 \mathrm{mg} / \mathrm{kg}), \mathrm{M}$ after washout $=$ rats pre-treated with methanandamide after methamphetamine "challenge dose" $(0.5 \mathrm{mg} / \mathrm{kg})$ following six days lasting wash-out period

$*=p<0.05, * *=p<0.01, \mathrm{NS}=$ non-significant - the non-parametric Wilcoxon matched pairs test.

Fig. 4. Effects of drug treatments in Experiment IV (subgroup $\mathrm{n}_{3}$ ) on Distance Travelled $(\mathrm{cm} / 3 \mathrm{~min})$ in the rat open field test shown as median values.

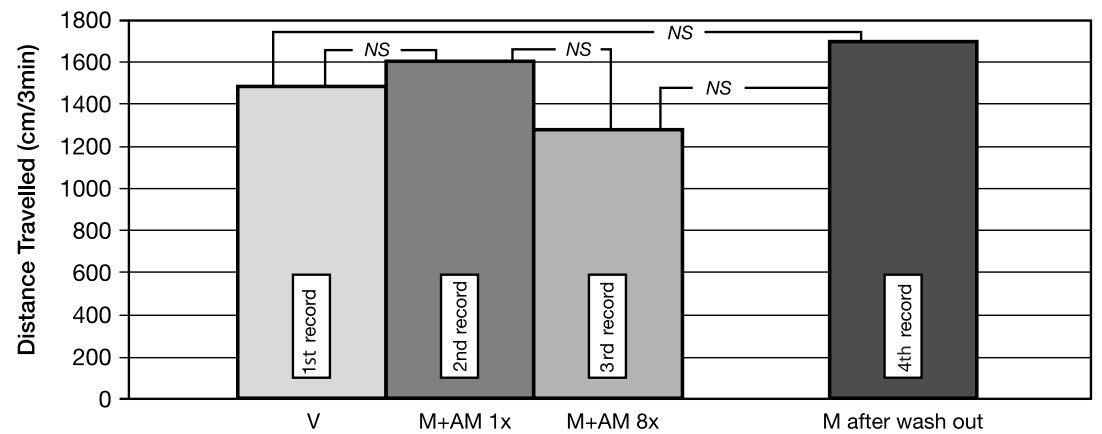

$\mathrm{V}=$ rats after the $1^{\text {st }}$ dose of vehicle $(2.0 \mathrm{ml} / \mathrm{kg}), \mathrm{M}+\mathrm{AM} 1 \mathrm{x}=$ rats after the $1^{\text {st }}$ dose of combined treatment methamphetamine $(0.5 \mathrm{mg} / \mathrm{kg})+\mathrm{AM} 251(2.0 \mathrm{mg} / \mathrm{kg}), \mathrm{M}+\mathrm{AM} 8 \mathrm{x}=$ rats pre-treated with the combined treatment after the $8^{\text {th }}$ dose of this combination (methamphetamine $[0.5 \mathrm{mg} / \mathrm{kg}]+$ AM 251 [2.0 mg/kg]), M after wash-out $=$ rats pre-treated with the combination of methamphetamine + AM 251 after methamphetamine "challenge dose" $(0.5 \mathrm{mg} / \mathrm{kg})$ following six days lasting wash-out period

$*=p<0.05, * *=p<0.01, \mathrm{NS}=$ non-significant - the non-parametric Wilcoxon matched pairs test.

compared to the animals that were administered vehicle (group $\mathrm{n}_{3}$, the $1^{\text {st }}$ record). Repeated administration of the combined treatment led to a non-significant decrease $(p>0.05)$ in Distance Travelled (group $n_{3}$, the $3^{\text {rd }}$ record versus the $2^{\text {nd }}$ record). The "challenge dose" of methamphetamine given after the wash-out on Day 21 did not result in significant changes in Distance Travelled (group $\mathrm{n}_{3}$, the $4^{\text {th }}$ record versus the $3^{\text {rd }}$ record) and the difference between the $4^{\text {th }}$ record and the $1^{\text {st }}$ record also did not reach statistical significance $(p>0.05)$ (Fig. 4).

\section{Discussion}

The results of the study of the impact of cannabinoid receptor ligands on sensitisation to methamphetamine effects on locomotor behaviour in rats were not consistent in subsequent 
experiments. When compared to acute methamphetamine effects, decreased behavioural responses (development of tolerance?) were manifested after repeated administration of methamphetamine ( significant after the dose of $5.0 \mathrm{mg} / \mathrm{kg} /$ day; just a trend without statistical significance after the lower dose of $2.5 \mathrm{mg} / \mathrm{kg} /$ day, which stimulated locomotion when given acutely) in the same experimental design used earlier in mice in which development of sensitisation (increased behavioural response) to stimulatory effect on locomotion was unambiguously confirmed instead. Nevertheless, in these experiments we observed an increased number of stereotypic acts after the "challenge dose" of methamphetamine, namely increased frequency of nose rubbing after both doses used. The occurrence of this is in accordance with findings of other authors (Laviola et al. 1999) and is suggested to express behavioural sensitisation, too. Unfortunately, we were not able to quantify exactly this indicator of behaviour using our technical equipment.

Concerning these in fact unexpected results of the first two rat experiments we wished to discern whether the decreased locomotor activity after repeated methamphetamine treatment with doses of 2.5 and $5.0 \mathrm{mg} / \mathrm{kg}$ was not a result of a too high dosage regimen. Therefore, in the next rat experiment animals were repeatedly pre-treated with the dose of $2.5 \mathrm{mg} / \mathrm{kg}$ but the "challenge dose" was only $1 \mathrm{mg} / \mathrm{kg}$. In this experiment we demonstrated a clear trend of increased locomotor activity measured after the "challenge dose" as a sign of potential behavioural sensitisation, although the changes still did not reach statistical significance.

In the further rat experiment we decided to check if the sensitising potential of methamphetamine can be more clearly manifested as an "expression of behavioural sensitisation" when testing of the "challenge dose" $(0.5 \mathrm{mg} / \mathrm{kg})$ effects is done after six days of wash-out from repeated drug treatment $(0.5 \mathrm{mg} / \mathrm{kg} /$ day $)$. Finally, in this last rat experiment both expression and development of behavioural sensitisation to methamphetamine effects on locomotor rat behaviour in the open field occurred.

Thus, these results show that, as previously in mice (Landa et al. 2006a), a repeated administration of methamphetamine can under certain circumstances elicit behavioural sensitisation to its stimulatory effects also in rats, which is in accordance with another report (Fukami et al. 2004). However, we were not able to provoke cross-sensitisation by repeated application of cannabinoid $\mathrm{CB}_{1}$ receptor agonist methanandamide, and similarly, we did not demonstrate suppression of the cross-sensitisation in rats that were repeatedly given combined pre-treatment of cannabinoid $\mathrm{CB}_{1}$ receptor antagonist AM 251 and methamphetamine as it was demonstrated in research carried out in mice. Possibly, the suggested interaction between the endocannabinoid system and processing of psychostimulant action of methamphetamine requires a cannabinoid dose that itself does not produce inhibitory effects on locomotion which was found in the present rat study, but not previously in mice.

Some authors discuss the role of habituation in rodents and data available from literature and concerning a possible influence of habituation on the behavioural sensitisation are not completely uniform. Ohmori et al. (2000) mention in their review that animals given a stimulant repeatedly in a test cage but not in other environments may show enhanced druginduced behaviour in the test cage. Crombag et al. (2001) report that doses of amphetamine or cocaine that fail to induce psychomotor sensitization when given to a rat in its home cage can produce robust sensitisation if given immediately following placement into a relatively novel, distinct environment. They found that the acute psychomotor response produced by an i.v. injection of $0.5 \mathrm{mg} / \mathrm{kg}$ amphetamine and the psychomotor sensitisation produced by repeated injections were greater when the drug treatments were given immediately after animals were placed into a distinct and relatively novel test environment, compared to when treatments were performed in a physically identical environment, but in which the animals lived (i.e., at home). Furthermore, habituation to the test environment for 
$6-8 \mathrm{~h}$ immediately prior to the drug administration completely abolished the effect of environmental novelty on the acute psychomotor response to amphetamine. This is not to a certain extent in accordance with our findings as our experimental design excluded habituation and despite this we were not able to provoke behavioural sensitisation in the first three rat experiments.

In conclusion, our investigation in these rat experiments showed that there are some interspecies differences in respect of neuronal plasticity changes induced by methamphetamine and underlying behavioural sensitisation to its effects. Those deserve to be analysed further in a wider dose range and with a particular interest paid to the rat stereotypic behaviour observed in our study. Some other authors become increasingly aware of not only species differences but also of strain differences in sensitisation to locomotor stimulation - e.g. after administration of morphine (Shuster 1984), which indicates that this phenomenon could also contribute to the differences between species and their susceptibility to drugs of abuse and in this way to possible elicitation of behavioural sensitisation. For instance, stimulatory effects of cocaine and amphetamine are larger in the Lewis rats than in the Fischer rats and furthermore the Lewis strain is more susceptible to the development of behavioural sensitisation than the animals of the Fischer strain (Kosten et al. 1994). These line differences in behavioural responses to the psychostimulants may be due to the larger amphetamine- and cocaine-induced increase of accumbal dopamine release in animals of the Lewis strain than in those of the Fischer strain (Camp et al. 1994). However, there is some evidence that these dissimilarities are at least partially due to differences in the bioavailability of these drugs (Camp et al. 1994).

Other authors make an attempt to evaluate the age-related differences in amphetamine and methamphetamine sensitization (Fujiwara et al. 1987; Kolta et al. 1990), noting that adult rats pre-treated with amphetamines display an augmentation of locomotor response when subsequently given an amphetamine "challenge dose". It has been shown that this sensitisation response does not occur until 3 - 4 weeks of age. The authors suggested that the appearance of mature presynaptic dopamine autoreceptors may be necessary for sensitisation (Fujiwara et al. 1987) or that maturation of dopamine reuptake sites is the limiting factor in the development of sensitisation (Fujiwara et al. 1987). Nevertheless, these findings related to the age of experimental animals are not in contradiction to our studies, as the age of the rats used for our purposes was about seven weeks at the beginning of each experiment.

\section{Vliv ligandů kanabinoidních receptorů na sensitizaci k účinkům metamfetaminu - ovlivnění lokomoční aktivity u potkanů}

Opakovaná aplikace různých zneuživaných látek může vést $\mathrm{k}$ postupně se zvyšující behaviorální odpovědi na tyto látky, zejména ke zvýšení lokomoce a možnému výskytu stereotypií. Tento fenomén je dobře znám a popsán jako behaviorální sensitizace. Zvýšená odpověd' na testovanou látku vyvolaná předchozí opakovanou aplikací látky odlišné je popisována jako zkř́žzená sensitizace. Na základě našich předchozích experimentů uskutečněných na myších, ve kterých byla potvrzena sensitizace k metamfetaminu a popsána zkřížená sensitizace $\mathrm{k}$ metamfetaminu po předchozí aplikaci agonisty kanabinoidních $\mathrm{CB}_{1}$ receptorů metanandamidu, jsme se $\mathrm{v}$ této studii zaměřili na užití jiného typického laboratorního zvířete - potkana. Pokud by výsledky studií u myší a potkanů byly podobné, zvýšila by se biologická validita sensitizačního fenoménu. Podobný výzkum u potkanů přinesl velmi podobné výsledky popsané dříve u myší. Nicméně, zaregistrovali jsme alespoň některé mezidruhové rozdíly ve vnímavosti potkanů k rozvoji sensitizace k metamfetaminovým účinkům. Ve srovnání s myším modelem bylo náročnější vytitrovat dávku metamfetaminu, která by behaviorální sensitizaci vyvolala. Dále jsme nebyli schopni vyvolat 
zkříženou sensitizaci pomocí opakované aplikace agonisty $\mathrm{CB}_{1}$ kanabinoidních receptorů metanandamidu a podobně se nám nepodařilo demonstrovat potlačení zkř́žzené sensitizace u potkanů, kterým byla opakovaně podávána kombinace antagonisty kanabinoidních $\mathrm{CB}_{1}$ receptorů látky AM 251 a metamfetaminu. Konečně, na rozdíl od myší, jsme namísto toho po opakované aplikaci metamfetaminu zaznamenali alternativní behaviorální změnu - výskyt stereotypního chování (otírání nosu).

\section{Acknowledgement}

This work was supported by the Czech Ministry of Education Project: VZ MSM0021622404 and Foundation for Development of Universities Project 450/2004.

\section{References}

CADONI C, PISANU A, SOLINAS M, ACQUAS E, DI CHIARA G 2001: Behavioural sensitization after repeated exposure to 9-tetrahydrocannabinol and cross-sensitization with morphine. Psychopharmacology 158: 259-266

CAMP DM, BROWMAN KE, ROBINSON TE 1994: The effects of methamphetamine and cocaine on motor behaviour and extracellular dopamine in the central striatum of Lewis versus Fischer-344 rats. Brain Res 6668 : 180-193

COSTA FG, FRUSSA-FILHO R, FELICIO FL 2001: The neurotensin receptor antagonist, SR48692, attenuates the expression of amphetamine-induced behavioural sensitisation in mice. Eur J Pharmacol 428: 97-103

CROMBAG HS, BADIANI A, CHAN J, DELL'ORCO J, DINEEN SP, ROBINSON TE 2001: The ability of environmental context to facilitate psychomotor sensitization to amphetamine can be dissociated from its effect on acute drug responsiveness and on conditioned responding. Neuropsychopharmacology 24: 680-690

DE VRIES TJ, SCHOFFELMEER AN, BINNEKADE R, VANDERSCHUREN LJ 1999: Dopaminergic mechanisms mediating the incentive to seek cocaine and heroin following long-term withdrawal of IV drug self-administration. Psychopharmacology 143: 254-260

DE VRIES TJ, SCHOFFELMEER AN, BINNEKADE R, RAASO H, VANDERSCHUREN LJ 2002: Relapse to cocaine- and heroin-seeking behaviour mediated by dopamine D2 receptors is time-dependent and associated with behavioural sensitization. Neuropsychopharmacology 26: 18-26

ELLIOT EE 2002: Cocaine sensitization in the mouse using a cumulative dosing regime. Behav Pharmacol 13: 407-415

FUJIWARA Y, KAZAHAYA Y, NAKASHIMA M, SATO M, OTSUKI S 1987: Behavioural sensitization to methamphetamine in the rat: an ontogenic study. Psychopharmacology (Berl.) 91: 316-319

FUKAMI G, HASHIMOTO K, KOIKE K, OKAMURA N, SHIMIZU E, IYO M 2004: Effect of antioxidant $\mathrm{N}$-acetyl-L-cysteine on behavioural changes and neurotoxicity in rats after administration of methamphetamine. Brain Res 30: 90-95

KALIVAS PW, SORG BA, HOOKS MS 1993: The pharmacology and neural circuitry of sensitization to psychostimulants. Behav Pharmacol 4: 315-334

KOLTA MG, SCALZO FM, ALI SF, HOLSON RR 1990: Ontogeny of the enhanced behavioural response to amphetamine in amphetamine-pretreated rats. Psychopharmacology (Berl.) 100: 377-382

KOSTEN TA, MISERENDINO MJD, CHI S, NESTLER EJ 1994: Fischer and Lewis rat strains show differential cocaine effects in conditioned place preference and behavioural sensitization but not in locomotor activity or conditioned taste aversion. J Pharmacol Exp Ther 269: 137-144

LAMARQUE S, TAGHZOUTI K, SIMON H 2001: Chronic treatment with Delta(9) - tetrahydrocannabinol enhances the locomotor response to amphetamine and heroin. Implications for vulnerability to drug addiction. Neuropharmacology 41: 118-129

LANDA L, ŠULCOVÁ A, ŠLAIS K 2006a: Involvement of cannabinoid CB1 and CB2 receptor activity in the development of behavioural sensitization to methamphetamine effects in mice. Neuroendocrinol Lett 27: 63-69

LANDA L, ŠLAIS K, ŠULCOVÁ A 2006b: Impact of cannabinoid receptor ligands on behavioural sensitization to antiaggressive methamphetamine effects in the model of mouse agonistic behaviour. Neuroendocrinol Lett 27: 703-710

LANIS A, SCHMIDT WJ 2001: NMDA receptor antagonists do not block the development of sensitization of catalepsy, but make its expression state-dependent. Behav Pharmacol 12: 143-149.

LAVIOLA G, ADRIANI W, TERRANOVA ML, GERRA G 1999: Psychobiological risk factors for vulnerability to psychostimulants in human adolescents and animal models. Neurosci Biobehav Rev 23: 993-1010

OHMORI T, ABEKAWA T, ITO K, KOYAMA T 2000: Context determines the type of sensitized behaviour: a brief review and a hypothesis on the role of environment in behavioural sensitization. Behav Pharmacol 11: 211-221

PIERCE RC, KALIVAS PW 1997: A circuitry model of the expression of behavioural sensitization to amphetamine-like psychostimulants. Brain Res Rev 25: 192-216 
ROBINSON TE, BERRIDGE KC 1993: The neural basis of drug craving: an incentive-sensitization theory of addiction. Brain Res Rev 18: 247-291

SHUSTER L 1984: Genetic determinants of responses to drugs of abuse: An evaluation of research strategies. In: SHARP, CW Mechanisms of tolerance and dependence. NIDA Res Mon 54: 50-69

TZSCHENTKE TM, SCHMIDT WJ 1997: Interactions of MK-801 and GYKI 52466 with morphine and amphetamine in place preference conditioning and behavioural sensitization. Behav Brain Res 84: 99-107

VINKLEROVÁ J, NOVÁKOVÁ J, ŠULCOVÁ A 2002: Inhibition of methamphetamine self-administration in rats by cannabinoid receptor antagonist AM 251. J Psychopharmacol 16: 139-143 
